P-ISSN: 2715-8098 E-ISSN: 2715-8101

\title{
PARADIGMA PEMBELAJARAN BAHASA ARAB DALAM INTEGRASI ILMU: KOMPARASI PEMIKIRAN IMAM SUPRAYOGO DAN AZHAR ARSYAD
}

\author{
Muhammad Rusydi \\ e-mail: rusydi.iainbone@gmail.com \\ Institut Agama Islam Negeri Bone
}

\begin{abstract}
Abstrak: Penelitian ini bertujuan untuk mengkomparasikan pemikiran dua tokoh yaitu Imam Suprayogo dan Azhar Arsyad tentang paradigma pembelajaran bahasa Arab dalam integrasi ilmu. Metode yang digunakan dalam penelitian ini adalah metode penelitian kepustakaan. Data dianalisis melalui tiga tahap, yaitu reduksi data, penyajian data, dan penarikan kesimpulan/verifikasi. Hasil penelitian menunjukkan bahwa metafora integrasi ilmu yang dirintis oleh keduanya, yaitu metafora pohon ilmu di UIN Maulana Malik Ibrahim Malang dan metafora cemara ilmu di UIN Alauddin Makassar, menunjukkan paradigma pembelajaran bahasa Arab dalam integrasi ilmu tersebut. Perbedaan posisi bahasa Arab beserta komponen yang menyertainya pada kedua metafora integrasi ilmu tersebut menunjukkan kerangka paradigmatik-metodologis dalam menguatkan bahasa Arab sebagai media integrasi ilmu yang dikembangkan oleh kedua tokoh tersebut. Kedekatan kerangka ontologis, epistemologis, dan aksiologis paradigma pembelajaran bahasa Arab dalam integrasi ilmu yang digagas keduanya melahirkan konsep ideal berupa konsep "ululalbab" oleh Imam Suprayogo yang diimplementasikan dalam bentuk Ma'bad al-Jamiah serta Program Khusus Pengembangan Bahasa Arab (PKPBA) pada UIN Maulana Malik Ibrahim Malang, dan melahirkan konsep "inner capacity" oleh Azhar Arsyad yang diimplementasikan dalam bentuk Program Pencerahan Imani dan Keterampilan Hidup (PIKIH) pada UIN Alauddin Makassar.
\end{abstract}

Kata Kunci: Paradigma pembelajaran, bahasa Arab, integrasi Iilmu, Imam Suprayogo, Azhar Arsyad.

\begin{abstract}
This study aims to compare the thoughts of two figures, Imam Suprayogo and Azhar Arsyad about the paradigm of learning Arabic in science integration. Library research method was used in this research. Data were analyzed through three stages, namely data reduction, data display, and drawing conclusions/verification. The results showed that the science integration metaphor pioneered by the two, namely the science tree metaphor at UIN Maulana Malik Ibrahim Malang and the pine tree metaphor at UIN Alauddin Makassar, described the paradigm of learning Arabic in the knowledge integration. The difference of Arabic position and its accompanying components in the two science integration metaphors indicated a paradigmatic-methodological framework in strengthening Arabic as a medium for science integration developed by the two figures. The closeness of the ontological, epistemological, and axiological framework of the Arabic learning paradigm in the science integration which was
\end{abstract}




\section{P-ISSN: 2715-8098 E-ISSN: 2715-8101}

initiated by both produced an ideal concept named "ululalbab" by Imam Suprayogo. This concept was implemented in the form of Ma'had al-Jamiah and the Arabic Language Development Special Program (PKPBA) at UIN Maulana Malik Ibrahim Malang. While, the concept of "inner capacity" produced by Azhar Arsyad was implemented in the form of Religious Enlightenment and Life Skills Program (PIKIH) at UIN Alauddin Makassar.

Keywords: Learning paradigm, Arabic language, integrated science, Imam Suprayogo, Azhar Arsyad

\section{PENDAHULUAN}

Paradigma pembelajaran bahasa Arab dalam lingkup perguruan tinggi keagamaan Islam, dalam konteks ke-Indonesiaan, terus menunjukkan perkembangan yang sangat dinamis. Pembelajaran bahasa Arab yang pada awalnya banyak berkutat pada wilayah struktur internal bahasa Arab seperti unsurunsur bahasa Arab yang mencakup Mufradat, Qawa'id, dan Ashwat, ilmu-ilmu bahasa Arab seperti Nahwu, Sharaf, Dilalah, Balagah, dan yang lainnya, serta keterampilan-keterampilan berbahasa Arab yang mencakup Kalam, Kitabah, Qiraah, dan Istima', (Nuha, 2016:74), sudah mulai mengalami perkembangan pada wilayah struktur internal bahasa Arab dengan dimensi pembelajaran bahasa Arab lainnya. Apabila pada wilayah struktur internal, paradigma pembelajaran bahasa Arab banyak berbicara tentang belajar bahasa Arab atau belajar tentang bahasa Arab maka pada wilayah struktur eksternal, pembelajaran bahasa Arab sudah mulai melakukan konstruk pembelajaran bahasa Arab dengan menekankan paradigma pembelajaran berupa belajar melalui bahasa Arab.

Perkembangan perguruan tinggi dengan realitas sosial sekitar telah membawanya pada suatu kegamangan paradigma keilmuan seiring dengan menguatnya semangat integrasi ilmu. Abu Darda mengemukakan bahwa perguruan tinggi mengemban misi untuk menjabarkan transformasi ilmu secara menyeluruh sehingga yang terjadi bukan sebatas transformasi ilmu dan keterampilan tapi juga transformasi nilai universal. Hal ini hanya akan terwujud apabila semangat universalitas tersebut dapat menjembatani integrasi antara ilmu agama dan ilmu umum (Darda, 2015: 38).

Hal yang sama juga dikemukakan Amin Abdullah bahwa ilmu, baik ilmu agama ataupun ilmu umum dengan berbagai disiplin keilmuan pengembangannya, merupakan suatu rangkaian yang saling terkait satu sama lain dalam paradigma interkoneksitas (Abdullah, 2006, viii). Menguatnya semangat untuk mengintegrasikan ilmu agama dan ilmu umum tersebut telah mendorong beberapa Perguruan Tinggi Keagamaan Islam (PTKI) di Indonesia melakukan transformasi kelembagaan. Dengan konsekuensi wider mandate yang dimiliki setelah transformasi kelembagaan tersebut, masing-masing PTKI terus mengembangkan paradigma pembelajaran, termasuk di dalamnya pembelajaran bahasa Arab.

Sosok Imam Suprayogo dan Azhar Arsyad merupakan dua tokoh yang tidak bisa dipisahkan dari penguatan pembelajaran bahasa Arab dalam spektrum integrasi ilmu PTKI. Hal yang menarik dari kedua tokoh tersebut adalah metafora integrasi ilmu yang digunakan memiliki kedekatan simbolis, yang mana Imam Suprayogo mengembangkan metafora pohon ilmu yang selanjutnya 
dikembangkan pada UIN Maulana Malik Ibrahim Malang (Suprayogo, 2005: 57), sementara Azhar Arsyad mengembangkan metafora cemara ilmu yang selanjutnya dikembangkan pada UIN Alauddin Makassar (Arsyad, 2009: 27).

Pemikiran kedua tokoh tersebut, dalam kaitannya dengan paradigma pembelajaran bahasa Arab dalam integrasi ilmu, menarik untuk dikaji dan dikomparasikan mengingat keduanya memiliki basis filosofi keilmuan yang kuat dengan seperangkat kerangka paradigmatik yang memiliki persinggungan ontologis, epistemologis, dan aksiologis satu sama lain pada beberapa aspek, di samping perbedaan-perbedaan yang menjadi karakteristik masing-masing.

\section{METODE PENELITIAN}

Metode yang digunakan dalam penelitian ini adalah metode penelitian kepustakaan dengan studi tokoh yang dalam hal ini adalah Imam Suprayogo dan Azhar Arsyad. Dalam tradisi keilmuan Islam, studi tokoh merupakan suatu jenis penelitian yang telah banyak diterapkan oleh banyak orang dengan karya-karya penelitian yang monumental seperti Thaha Husein yang dalam penelitiannya dengan judul "Drikera Abi al-A'la", menulis pemikiran Abi al-A'la terkait sastra Arab, Muhammad Abed al-Jabiri dalam penelitiannya dengan judul "al-Fikr Ibn Khaldun: al-Ashabiyah wa al-Dawlah, menulis pemikiran Ibn Khaldun terkait 'ashabiyah dan kerajaan, Sayyed Hossein Nasr dalam penelitiannya dengan judul "Sadr Syirazi and His Trancendent Theosophy" menulis pemikiran Ibn Khaldun terkait al-Syirazi dan teosofi transendennya, Harun Nasution dalam penelitian disertasinya pembedah pemikiran teologi Muhammad Abduh lalu melihatnya dalam perspektif teologi rasional Mu'tazilah, Nurcholis Madjid dalam penelitian disertasinya pembedah pemikiran kalam dan filsafat dari Ibnu Taimiyah, dan yang lainnya (Harahap, 2014: 16-20).

Berdasarkan Model Miles dan Huberman, proses pengolahan dan analisis data dalam penelitian dilakukan melalui tiga tahapan secara berkesinambungan. Tahap reduksi data (data reduction) merupakan suatu proses pemilihan, pemusatan perhatian untuk menyederhanakan data kasar yang diperoleh pada berbagai lieratur dimana kegiatan ini dilakukan secara berkesinambungan sejak awal penelitian hingga akhir pengumpulan data. Tahap penyajian data (data display) yaitu tahap menyajikan data yang sudah direduksi dan diorganisasikan secara keseluruhan dalam bentuk naratif deskriptif. Adapun tahap penarikan kesimpulan/verifikasi (conclusion drawing/verivication) adalah tahap dimana peneliti merumuskan kesimpulan dan memverifikasi setelah melakukan tahap reduksi dan penyajian data. Apabila kesimpulan yang ditarik belum mendapatkan bukti-bukti yang kuat dalam mengungkap tema yang ditulis, pengumpulan data kembali dilanjutkan. Tapi apabila kesimpulan yang ditetapkan sudah didukung oleh data-data yang valid dan akurat sehingga sudah mampu mengungkap tema yang ditulis, kesimpulan tersebut sudah dapat diterima (Sugiyono, 2008: 337-345).

\section{HASIL DAN PEMBAHASAN}

\section{Pemikiran Imam Suprayogo tentang Paradigma Pembelajaran Bahasa Arab dalam Integrasi Ilmu}

Imam Suprayogo lahir di Trenggalek, Jawa Timur pada 2 Januari 1951. (Taufiqurrahman, 2010: 5). Pemberian nama "Imam" pada awal nama Imam Suprayogo ternyata telah menjadi doa dan pemacu semangat baginya. Salah satu poin penting dari visi pengembangan PTKI yang 
ditawarkan Imam Suprayogo adalah pembentukan karakter peserta didik sehingga menjadi intelektual yang dibekali dengan nilai-nilai karakter. Pendidikan, menurutnya, memiliki dimensi yang lebih luas dibandingkan dengan pengajaran dimana pendidikan menekankan pendekatan yang holistik mulai dari kedalaman pengetahuan, penguasaan keterampilan, sampai pada pembentukan karakter dari pendidik kepada peserta didik (Suprayogo, 2013: 4).

Semangat ini yang selalu mendorong Imam Suprayogo untuk mengembangkan konsep "ulul albab" sebagai basis pembentukan karakter peserta didik pada UIN Maulana Malik Ibrahim Malang. Konsep "ulul albab" yang dikembangkan Imam Suprayogo ini dalam perkembangannya menjadi magnum opus visi kelembagaan UIN Maulana Malik Ibrahim Malang dalam melakukan penguatan integrasi ilmu. Hal ini ditegaskan oleh Imam Suprayogo bahwa pendidikan harus diorientasikan untuk membentuk nilainilai luhur dan harus didukung dengan menjaga suasana jiwa dan batin peserta didik untuk senantiasa berada pada berbagai aktivitas pembelajaran yang terintegrasi (Suprayogo, 2011: 388).

Berbagai gagasan cemerlang yang dikemukakan Imam Suprayogo pada upaya mengakselerasi paradigma pembelajaran bahasa Arab dalam integrasi ilmu menarik untuk dicermati. Latar belakang pendidikannya yang notabene bukan bahasa Arab tapi pada bidang sosiologi tidak menjadi penghalang baginya dalam berinovasi melalui progam-program inovatif pada pembelajaran bahasa Arab yang pada akhirnya mendudukkan UIN Maulana Malik Ibrahim yang pernah dipimpinnya sebagai salah satu kiblat, kalau mengatakan kiblat utama terlalu berlebihan, pembelajaran bahasa Arab perguruan tinggi keagamaan Islam di Indonesia. Dengan latar keilmuan pada bidang sosiologi, Imam Suprayogo sangat paham bahwa belajar bahasa Arab akan semakin bermakna apabila belajar pada orang Arab atau bersama dengan peserta didik yang berasal dari negara-negara yang menggunakan bahasa Arab sebagai bahasa pengantar komunikasi sehari-hari sehingga dengan kekuatan manajerial bidang kerjasama kelembagaan, UIN Maulana Malik Ibrahim Malang yang pernah dipimpinnya mampu mendatangkan banyak dosen tamu dan mahasiswa yang berasal dari berbagai negara yang dimaksud seperti Sudan, Libya, Saudi Arabiyah, Maroko, dan yang lainnya.

Dalam upayanya untuk mewujudkan konsep "ulul albab" tersebut, Imam Suprayogo, dalam periode kepemimpinannya yang berlangsung dari 1998-2013 dengan transformasi kelembagaan yang masif mulai dari UIIS, STAIN Malang, sampai UIN Maulana Malik Ibrahim Malang, terus berupaya melakukan inovasi paradigma pengelolaan kelembagaan yang salah satunya adalah membangun basis filosofis integrasi ilmu. Upaya ini diwujudkan dengan mengembangkan peradigma integrasi ilmu melalui metafora pohon ilmu yang sarat dengan makna filosofis di dalamnya yang dapat digambarkan sebagai berikut:

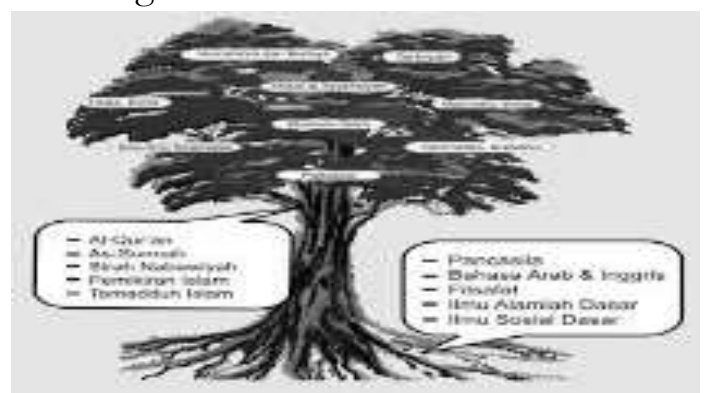


Gambar 1: Metafora Pohon Ilmu

Sumber: Suprayogo, 2005: 57

Makna filosofis yang tergambar dalam metafora pohon ilmu tersebut digambarkan Arbi dkk. (2018: 12), dengan mengutip Imam Suprayogo, bahwa akar yang terbangun atas Pancasila, bahasa Arab, bahasa Inggris, filsafat, Ilmu Alamiah Dasar, serta Ilmu Sosial Dasar merupakan seperangkat pengetahuan instrumental yang dapat digunakan dalam pengembangan ilmu pengetahuan sekaligus sebagai fondasi supaya pohon ilmu tidak mudah goyah. Batang pohon ilmu yang terbangun atas al-Qur'an, as-Sunnah, sirah Nabawiyah, pemikiran Islam, serta tamaddun Islam dapat dipahami sebagai seperangkat ilmu yang berasal dari kelima aspek tersebut yang tidak bisa dipisahkan dari pengetahuan instrumental yang terdapat pada akar.

Dalam konteks ini, dapat dipahami bahwa untuk dapat mempelajari al-Qur'an, as-Sunnah, sirah Nabawiyah, pemikiran Islam, serta tamaddun Islam, kemampuan Pancasila, bahasa Arab, bahasa Inggris, filsafat, Ilmu Alamiah Dasar, serta Ilmu Sosial Dasar mutlak diperlukan. Cabang, ranting, dan daun pohon ilmu terdiri atas berbagai disiplin ilmu seperti kedokteran, filsafat, psikologi, ekonomi, dan lainnya yang harus dipilih oleh peserta didik sebagai basis profesionalitas keilmuannya. Kekuatan cabang, ranting, dan daun pohon ilmu sangat ditentukan oleh asupan saripati makanan dari batang sampai akar.

Dalam metafora pohon ilmu yang digagas Imam Suprayogo dan dikembangkan di UIN Maulana Malik Ibrahim Malang tersebut, terlihat posisi bahasa Arab berada pada akar bersama dengan seperangkat pengetahuan instrumental lain yaitu Pancasila, bahasa Inggris, filsafat, Ilmu Alamiah Dasar, serta Ilmu Sosial Dasar yang diilustrasikan sebagai pondasi struktur integrasi keilmuan yang dikembangkan. Hal inilah yang mendorong Imam Suprayogo mengakselerasi pembelajaran bahasa Arab melalui Ma'had al-Jamiah serta Program Khusus Pengembangan Bahasa Arab (PKPBA).

Kedua lembaga tersebut memberikan penekanan terhadap mahasiswa khususnya pada tahun pertama, atau semester satu dan dua, untuk mempelajari bahasa Arab secara intensif dengan titik penekanan pada kemampuan berkomunikasi, berliterasi, serta bereksplorasi pada berbagai buku bahasa Arab klasik yang membahas studi-studi Islam ala tradisi pesantren pada umumnya dan buku-buku teks yang berkaitan dengan latar keilmuan masing-masing berdasarkan fakultas yang ada di lingkungan UIN Maulana Malik Ibrahim Malang.

Hal yang mendasari Imam Suprayogo dalam mengakselerasi pembelajaran bahasa Arab dalam bentuk program-program pembelajaran bahasa Arab inovatif yang kemudian menjadikan UIN Maulana Malik Ibrahim Malang sebagai salah satu ikon PTKI di Indonesia dengan pembelajaran bahasa Arabnya adalah keinginan untuk memfasilitasi peserta didik untuk lebih leluasa dalam menerapkan ilmunya (Suprayogo, 2007: 81).

Hal ini bisa ditemukan pada ungkapan yang dikemukakannya bahwa banyak alumni PTKI yang tidak memiliki kemampuan berbahasa Arab sehingga berimplikasi praktis pada rendahnya cakrawala pengetahuan agama mereka yang boleh dikatakan 
masih di bawah standar. Kelemahan tersebut, pada gilirannya, membuat mereka tidak mampu menjalankan peran-peran profesionalitas mereka sebagai alumni PTKI yang sudah seharusnya dalam upacara keagamaan dengan menggunakan teks berbahasa Arab misalnya (Suprayogo, 1996: 49).

Daya pikir konstruktif yang dimiliki Imam Suprayogo dengan mengangkat metafora pohon ilmu, dalam perspektif semiotika, mengisyaratkan bahwa perlunya manusia menjadikan alam, yang disimbolkan dengan pohon, sebagai media dalam ber-tafakkeur. Hal ini seperti yang digambarkan Mahzar bahwa manusia perlu mengekslorasi sandi-sandi alam semesta untuk mendapatkan dan mengembangkan ilmu pengetahuan (Mahzar, 2004: 35). Fenomena integrasi ilmu yang menggunakan alam sebagai simbol metafora integrasi ilmu yang dikembangkan juga dapat ditemukan pada PTKI lainnya.

\section{Pemikiran Azhar Arsyad tentang Paradigma Pembelajaran Bahasa Arab dalam Integrasi Ilmu}

Azhar Arsyad lahir di Toli-Toli, Sulawesi Tengah pada 3 Mei 1952. Kontribusi Azhar Arsyad sebagai salah seorang pembaharu pembelajaran bahasa Arab di Indonesia tidak diragukan lagi. Inovasi pembelajaran bahasa Arab yang ditawarkannya menekankan penguatan mufradat lalu didukung dengan kemampuan untuk menerapkan metode drill dari uslub popular bahasa Arab mulai dari uslub yang sederhana sampai pada uslub yang kompleks.

Dalam upaya untuk mengakselerasi dimensi komunikatif penggunaan bahasa Arab tersebut,
Azhar Arsyad menekankan perlunya kejelian dalam pemilihan mufradat yang akan diajarkan pada peserta didik seperti popularitas, universalitas, dan aksebilitas (Arsyad, 2012: 44). Upaya ini yang kemudian mewarnai pembaharuan pembelajaran bahasa Arab yang dilakukan Azhar Arsyad sehingga sebagai langkah sederhana tapi sangat menginspirasi pembelajaran bahasa Arab bagi pemula yaitu dengan menerbitkan dua buku bahasa Arab, Dasar-Dasar Penguasaan Babasa Arab melalui Kata Benda Populer Bahasa Arab dan Menguasai Kata Kerja Populer dan Preposisi Bahasa Arab.

Beberapa pokok pikiran yang menginspirasi Azhar Arsyad dalam melakukan pembaharuan pembelajaran bahasa Arab yaitu:

a. Bahasa merupakan semacam tingkah laku, baik verbal ataupun non verbal, yang mempunyai maksud tertentu di antara manusia.

b. Orang yang memiliki sikap defensif dalam mempelajari bahasa akan mengalami kesulitan untuk belajar kalau bukan kegagalan.

c. Peserta didik harus disibukkan dengan aktivitas belajar bahasa.

d. Pemakaian bahasa secara aktif dan komunikatif sejak awal dapat mengakselerasi motivasi integratif peserta didik dalam belajar bahasa.

e. Serta peserta didik hanya akan berhasil mempelajari bahasa asing apabila mereka dilibatkan secara utuh (Arsyad, 2010: 33-34).

Sebagai kerangka praktis dari pokok pikiran tersebut, Azhar Arsyad kemudian memberikan beberapa trik khusus dalam mewujudkannya pada tataran praktis yaitu:

a. Persiapan yang memadai.

b. Pendidik mengunakan bahasa Arab dalam kelas. 
c. Pendidik tidak boleh pindah materi berikutnya sebelum mantap dan tidak boleh terpengaruh jawaban bersama.

d. Buku ajar bukan satu-satunya sumber belaja.

e. Peserta didik dibiasakan dengan banyak latihan berbahasa.

f. Peserta didik dilatih banyak bertanya dengan menggunakan bahasa Arab.

g. Pendidik selalu memberi semangat belajar pada peserta didik.

h. Serta perlunya menciptakan suasana belajar yang menyenangkan. (Arsyad, 2016: 11)

Perhatiannya yang sangat besar terhadap bahasa Arab dan pembelajarannya mendorong Azhar Arsyad untuk memasukkan bahasa Arab sebagai bagian integral dari proses integrasi ilmu yang dirintisnya mengiringi transformasi kelembagaan IAIN Alauddin Makassar menuju UIN Alauddin Makassar sebagaimana tergambar dalam metafora cemara ilmu berikut.

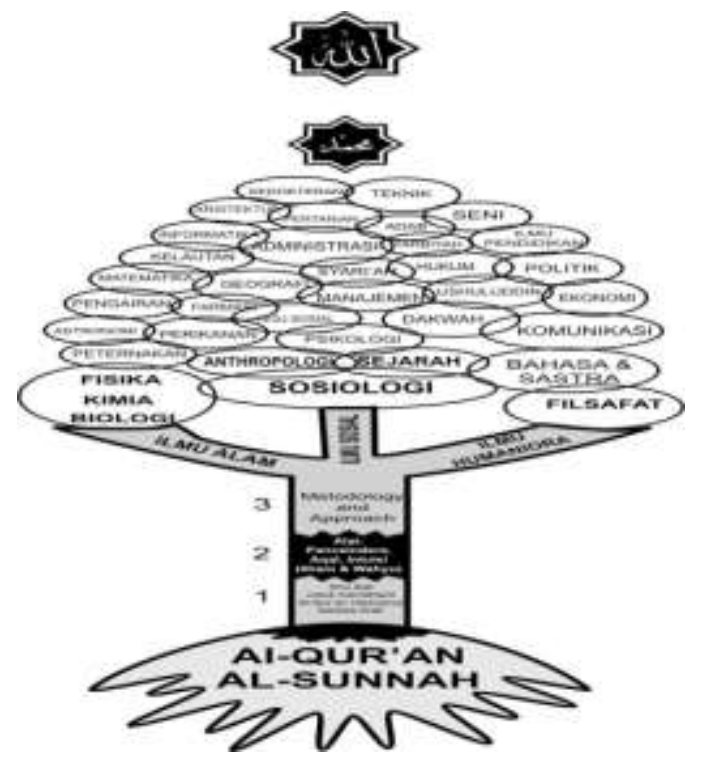

Gambar 2: Metafora Cemara Ilmu

Sumber: Arsyad, 2011: 27
Dalam metafora cemara ilmu tersebut, terlihat bagaimana Azhar Arsyad menempatkan al-Qur'an dan alSunnah pada posisi akar. Fungsi akar pada tumbuhan adalah sebagai sumber saripati makanan dari dalam tanah pada satu sisi dan juga menjadi pegangan agar tumbuhan tersebut dapat berdiri dengan kokoh. Fungsi al-Qur'an dan alSunnah dalam integrasi ilmu juga demikian. dimana keduanya menjadi magnum opus kajian sekaligus sebagai pegangan normatif teologis dalam penerapannya.

Pada bagian batang, terlihat bahwa ada tiga komponen yang terjalin secara hirarkis yang dalam hal ini adalah bahasa Arab sebagai alat untuk memahami al-Qur'an pada bagian awal dari batang. Selanjutnya, alat untuk memperoleh ilmu yang terdiri atas panca indera, akal, serta intuisi berbasis ilham dan wahyu. Bagian batang yang terakhir adalah metodologi dan pendekatan.

Ketika saripati makanan yang diperoleh akar dari dalam tanah dikirim ke batang untuk selanjutnya didistribusikan pada bagian-bagian pohon lainnya, maka konsep integrasi ilmu dalam metafora cemara ilmu adalah bagaimana mendudukkan ketiga komponen yang terdapat dalam metafora batangnya sebagai alat yang menjembatani penjabaran praktis nilainilai normatif teologis yang imanen dalam al-Qur'an dan al-Sunnah untuk selanjutnya dibawa ke cabang cemara ilmu yang dalam hal ini terdiri atas ilmu alam, ilmu sosial, dan ilmu humaniora.

Dari ketiga cabang tersebut yang kemudian berkembang menjadi dahan, ranting, dan daun berupa berbagai disiplin ilmu berdasarkan klasifikasi ketiga rumpun ilmu, baik itu ilmu alam, ilmu sosial, ataupun ilmu humaniora. 
Buah dari cemara ilmu selanjutnya yang digambarkan sebagai karakter intelektual hasil integrasi ilmu yang beriman, beramal shaleh, serta berakhlak mulia (Arsyad, 2009: 26-28).

Dalam kerangka filosofisnya, buah cemara ilmu ini kemudian lebih dikenal dengan konsep "inner capacity" sebagai usaha pengembangan kreativitas, proaktivitas, inovasi, dan imajinasi berbasis daya hidup, daya daya piker, dan daya kalbu (Arsyad, 2009: 63).

Menyikapi komitmen Azhar Arsyad terkait penguatan paradigma pembelajaran bahasa Arab dalam integrasi ilmu, Mansyur Ramly mengemukakan bahwa salah satu ide cemerlang Azhar Arsyad dalam visi kepemimpinannya adalah dengan mengembangkan berbagai program unggulan berbasis penguatan inner capacity. Konsep inner capacity yang ditawarkan Azhar Arsyad tersebut merefleksikan teori gunung es yang menggambarkan bahwa potensi manusia yang terlihat berupa hard skill boleh jadi masih seperti puncak gunung es yang timbul sedikit pada permukaan laut sementara bagian gunung es yang lebih besar masih tidak terlihat layaknya potensi yang lebih besar berupa soft skill masih perlu digali lebih lanjut pada diri peserta didik (Ramly, 2010: 56-57).

Salah satu program unggulan yang ditawarkan Azhar Arsyad dalam mengakselerasi inner capacity tersebut adalah Program Pencerahan Imani dan Keterampilan Hidup (PIKIH), sebuah program pembelajaran bahasa asing pada tahun pertama kuliah di lingkungan UIN Alauddin Makasar, baik bahasa Arab ataupun bahasa Inggris, yang dipadukan dengan penguatan nilai-nilai karakter melalui berbagai kata-kata hikmah pendorong motivasi.

\begin{abstract}
Melalui Program Pencerahan Imani dan Keterampilan Hidup (PIKIH), Azhar Arsyad telah melakukan penguatan paradigma pembelajaran bahasa Arab dalam integrasi ilmu dimana peserta didik diarahkan untuk belajar bahasa Arab yang dimulai dengan pengenalan komunikasi berbahasa Arab sederhana sampai pada pembelajaran bahasa Arab yang disesuaikan dengan latar keilmuan peserta didik berupa Ta'lim al-Lugah alArabiyah li al-Agradh al-Khassah.
\end{abstract}

3. Komparasi Pemikiran Imam Suprayogo dan Azhar Arsyad tentang Paradigma Pembelajaran Bahasa Arab dalam Integrasi Ilmu

Dalam komparasi pemikiran Imam Suprayogo dan Azhar Arsyad tentang paradigma pembelajaran bahasa Arab dalam integrasi ilmu, penulis merujuk pada beberapa aspek yang menjadi pijakan paradigma pembelajaran bahasa Arab pada UIN Maulana Malik Ibrahim Malang dan UIN Alauddin Makassar. Sebagai pijakan dalam komparasi tersebut, penulis merujuk pada tiga hal penting yang dalam hal ini adalah posisi paradigma pembelajaran bahasa Arab dalam metafora integrasi ilmu, peran paradigma pembelajaran bahasa Arab dalam pencapaian konsep ideal integrasi ilmu, dan implemetasi paradigma pembelajaran bahasa Arab dalam lokus integrasi ilmu.

Posisi paradigma pembelajaran bahasa Arab dalam metafora integrasi ilmu menarik untuk dicermati dari halhal yang dikemukakan oleh Imam Suprayogo dan Azhar ketika keduanya menggunakan metafora integrasi ilmu yang hampir sama untuk tidak mengatakan sama. Hal yang menarik untuk dicermati adalah adanya 
$\begin{array}{llr}\text { perbedaan } & \text { mendasar dalam } \\ \text { memposisikan } & \text { bahasa Arab pada }\end{array}$ masing-masing metafora integrasi ilmu yang ditawarkan. Dalam metafora pohon ilmu yang dikemukakan Imam Suprayogo, paradigma pembelajaran bahasa Arab diposisikan sebagai akar bersama dengan seperangkat pengetahuan instrumental lain yaitu Pancasila, bahasa Inggris, filsafat, Ilmu Alamiah Dasar, serta Ilmu Sosial Dasar.

Dalam konteks tersebut, akar dipahami sebagai pondasi yang memperkuat pijakan integrasi ilmu dalam berbagai perspektifnya sehingga dengan menguasai bahasa Arab beserta dengan seperangkat pengetahuan instrumental tersebut, peserta didik akan mampu untuk mengembangkan kerangka keilmuan berbasis studi Islam berikutnya yaitu al-Qur'an, as-Sunnah, sirah Nabawiyah, pemikiran Islam, serta tamaddun Islam. Dalam hal inilah, Imam Suprayogo menekankan perlunya penguasaan bahasa Arab sebagai media untuk mengaji dan mengkaji berbagai literatur studi Islam tersebut yang tertulis dalam bahasa Arab. Setelah memiliki penguasaan terkait dengan kerangka keilmuan berbasis studi Islam yang ada pada batang metafora pohon ilmu barulah peserta didik di arahkan untuk menggunakan pengetahuan dan keterampilan bahasa Arab yang dikuasainya untuk mendalami berbagai disiplin ilmu berbasis fakultas dan jurusan yang ada pada UIN Maulana Malik Ibrahim Malang.

Adapun Azhar Arsyad dalam menggambarkan paradigma pembelajaran bahasa Arab pada metafora cemara ilmu yang dikemukakannya, memposisikan alQur'an dan al-Sunnah pada bagian akar. Hal ini mengisyaratkan bahwa integrasi ilmu yang ditawarkan Azhar
Arsyad memberikan penegasan bahwa posisi al-Qur'an dan al-Sunnah sebagai magnum opus ajaran Islam harus menjadi pondasi dari semua kerangka konseptual dan implementatif integrasi ilmu layaknya akar yang menjadi pagangan sekaligus sumber saripati makanan dari tanah. Posisi paradigma pembelajaran bahasa Arab dalam metafora cemara ilmu yang dikembangkan Azhar Arsyad tersebut baru terlihat pada bagian batang menggambarkan bahwa ada tiga hal dalam menjembatani dimensi teologis normatif yang ada pada al-Qur'an dan al-Sunnah untuk dapat dikembangkan pada kerangka integrasi ilmu yaitu ilmu alat yang terdiri atas bahasa Arab, alat untuk memperoleh ilmu yang terdiri atas panca indera, akal, serta intuisi berbasis ilham dan wahyu serta metodologi dan pendekatan. Disinilah perbedaan mendasar dari paradigma pembelajaran bahasa Arab yang ditawarkan Azhar Arsyad yang menempatkan bahasa Arab pada bagian batang dengan paradigma pembelajaran bahasa Arab yang ditawarkan Imam Suprayogo yang menempatkan bahasa Arab pada bagian akar.

Hal yang menarik kemudian untuk dicermati dari posisi paradigma pembelajaran bahasa Arab pada kedua metafora integrasi ilmu tersebut adalah ketika bahasa Arab diletakkan pada akar metafora pohon ilmu bersama Pancasila, bahasa Inggris, filsafat, Ilmu Alamiah Dasar, serta Ilmu Sosial Dasar dan ketika bahasa Arab diletakkan pada batang metafora cemara ilmu bersama alat untuk memperoleh ilmu yang terdiri atas panca indera, akal, serta intuisi berbasis ilham dan wahyu serta metodologi dan pendekatan.

Dalam hal ini dapat dipahami bahwa posisi Azhar Arsyad sebagai 
tokoh dengan latar belakang bahasa dan pembelajarannya telah memberikan kerangka metodologis yang kuat untuk mengakselerasi pembelajaran bahasa Arab sebagai basis integrasi ilmu yang dikembangkan. Panca indera, akal, serta intuisi dalam perkembanganya bermetamorfosis menjadi pembelajaran bahasa Arab yang fokus pada berbagai obyek empiris melalui indera dengan banyak mengeksplorasi arti mufradat dari benda-benda yang ada di lingkungan pembelajaran, pembelajaran bahasa Arab yang fokus pada analisis logis dengan penekanan pada metode drill dari uslub popular bahasa Arab, serta pembelajaran bahasa Arab yang fokus pada pemberian intuitif dengan penekanan pada penguatan motivasi intrinsik dan ekstrinsik berupa pemberian kata-kata hikmah dan kisah inspiratif seperti arriyhu wa as-syamsu yang memberi pesan inspiratif tentang kemenangan strategi dalam menundukkan kekuatan (Arsyad, 2002:4).

Upaya itu kemudian, dalam pemikiran Azhar Arsyad, harus diperkuat dengan metodologi dan pendekatan sebelum ke cabang, dahan, ranting, dan daun metafora cemara ilmu. Ketiga komponen dalam batang matafora cemara ilmu tersebut diterapkan secara berjenjang. Sementara itu, Imam Suprayogo yang menempatkan bahasa Arab bersama dengan seperangkat pengetahuan instrumental lain yaitu Pancasila, bahasa Inggris, filsafat, Ilmu Alamiah Dasar, serta Ilmu Sosial Dasar berarti menempatkan bahasa Arab sebagai alat untuk menguatkan integrasi ilmu bersama dengan pengetahuan instrumental tersebut yang harus bersinergi satu sama lain secara simultan. Hal yang menarik untuk dicermati adalah metafora pohon ilmu tetap bertahan sebagai metafora integrasi ilmu sampai sekarang pada UIN Maulana Malik Ibrahim Malang, sementara metafora cemara ilmu sudah berganti menjadi metafora integrasi ilmu dalam bentuk lain yaitu metafora rumah peradaban dan metafora kereta keilmuan pada UIN Alauddin Makassar.

Peran paradigma pembelajaran bahasa Arab dalam pencapaian konsep ideal integrasi ilmu yang dikembangkan oleh Imam Suprayogo berupaya untuk melahirkan konsep "ulul albab", sementara Azhar Arsyad berupaya untuk melahirkan konsep "inner capacity". Dalam mengukur tingkat keberhasilan dari peran paradigma pembelajaran bahasa Arab dalam pencapaian konsep ideal integrasi ilmu berbasis konsep "ulul albab", Imam Suprayogo, sebagaimana dikutip Rahmat Aziz, mengemukakan bahwa keberhasilan konsep "ulul albab" dalam berbagai dimensi pembelajaran yang berlangsung pada UIN Maulana Malik Ibrahim Malang dapat diukur dari lahirnya output pembelajaran yang:

a. Berpengetahuan luas

b. Berpandangan tajam

c. Berotak cerdas

d. Berhati lembut

e. Serta bersemangat juang tinggi karena Allah sebagai pengejawantahan amal shaleh (Aziz, 2007: 311). Penjabaran praktis dari konsep "ulul albab" ini kemudian disederhanakan pada empat poin yaitu kedalaman spiritual, keagungan akhlak, keluasan ilmu, serta kematangan professional. Sementara itu, Azhar Arsyad dalam menggambarkan peran paradigma pembelajaran bahasa Arab dalam pencapaian konsep ideal 
integrasi ilmu adalah bagaimana mewujudkan konsep ideal yang disebut "inner capacity" yang merupakan penguatan potensi terdalam yang pada dasarnya imanen dalam diri setiap peserta didik.

Konsep "inner capacity" menurut Azhar Arsyad dan Mauhammad Sabri terbangun atas daya fisik, daya kalbu, daya pikir, serta daya hidup. Konsekuensi praktisnya, paradigma pembelajaran bahasa Arab dalam integrasi ilmu harus mampu melahirkan peserta didik yang kuat (daya fisik), baik hati (daya kalbu), cerdas (daya pikir), serta kreatif (daya hidup) (Arsyad \& Sabri, 2009: 116-120). Dalam masa kepemimpinannya pada UIN Alauddin Makassar, Azhar Arsyad lebih banyak menekankan implementasi konsep "inner capacity" dengan tiga komponennya yaitu daya hidup, daya kalbu, dan daya pikir. Upaya untuk mewujudkan konsep ideal integrasi ilmu tersebut, baik "ulul albab" ataupun "inner capacity", sangat memungkinkan untuk dilakukan dengan menguatkan paradigma pembelajaran bahasa Arab melalui penguatan kerangka ontologis, epistemologis, serta aksiologis pembelajarannya.

Pemikiran Imam Suprayogo terkait implementasi paradigma pembelajaran bahasa Arab dalam lokus integrasi ilmu diwujudkan pada UIN Maulana Malik Ibrahim Malang dalam membentuk Ma'had al-Jamiah serta Program Khusus Pengembangan Bahasa Arab (PKPBA). Adapun Azhar Arsyad, dalam pemikirannya, terkait implementasi paradigma pembelajaran bahasa Arab dalam lokus integrasi ilmu diwujudkan pada UIN Alauddin Makassar dengan membentuk Program Pencerahan Imani dan Keterampilan Hidup (PIKIH).
Dalam pemikiran kedua tokoh tersebut, pembentukan lingkungan berbahasa merupakan kunci dari kesuksesan pembelajaran bahasa Arab. Hal inilah yang diwujudkan oleh Imam Suprayogo dengan lahirnya konsep Ma'bad al-Jamiah pada UIN Maulana Malik Ibrahim Malang dimana semua peserta didik pada tahun pertama diwajibkan untuk tinggal di asrama dengan berbagai disiplin keilmuan seperti penguasaan bahasa asing, bahasa Arab, dan bahasa Inggris, kajian Islam, seni Islam, dan semacamnya, yang kemudian didukung dengan pembelajaran bahasa Arab pada Program Khusus Pengembangan Bahasa Arab (PKPBA) yang diselenggarakan oleh Pusat Pengembangan Bahasa UIN Maulana Malik Ibrahim Malang.

Konsep pembelajaran bahasa Arab dengan sistem asrama ini, dalam kepemimpinan Azhar Arsyad pada UIN Alauddin Makassar, hanya berlaku terbatas pada Jurusan Tafsir Hadits Program Khusus karena keterbatasan sarana asrama saat itu. Terkait dengan pembentukan lingkungan berbahasa Arab ini melalui sistem ma'bad, pada dasarnya, juga sangat didukung Azhar Arsyad seperti yang dikemukakannya bahwa penerapan konsep pembinaan peserta didik berbasis ma'bad sangat perlu diterapkan pada PTKI untuk mengintensifkan pembinaan kepada mereka dengan berbagai pengetahuan dan keterampilan seperti penguasaan bahasa asing, bahasa Arab dan bahasa Inggris, budaya hidup teratur dan bersih, wawasan multikultural, kewirausahaan, dan semacamnya (Arsyad, 2005: 53). 


\section{SIMPULAN}

Berdasarkan uraian pada bagian sebelumnya, dapat disimpulkan bahwa pemikiran Imam Suprayogo terkait paradigma pembelajaran bahasa Arab dalam integrasi ilmu diwarnai semangat integrasi studi Islam dengan berangkat dari tipologi ilmu-ilmu yang diintegrasikan untuk selanjutnya menjadikan bahasa Arab beserta seperangkat pengetahuan instrumental lain yaitu Pancasila, bahasa Inggris, filsafat, Ilmu Alamiah Dasar, serta Ilmu Sosial Dasar untuk menguatkannya. Berbeda dengan Azhar Arsyad, dalam pemikirannya, bahasa Arab ditempatkan bersama alat untuk memperoleh ilmu yang terdiri atas panca indera, akal, serta intuisi berbasis ilham dan wahyu, serta metodologi dan pendekatan untuk menguatkan integrasi ilmu.

Penggunaan metafora integrasi ilmu berupa pohon ilmu dan cemara ilmu dari kedua tokoh menunjukkan kedekatan kerangka ontologis, epistemologis, dan aksiologis paradigma pembelajaran bahasa Arab dalam integrasi ilmu yang digagas keduanya. Yang membedakan keduanya adalah posisi dan komponen lain yang menyertai bahasa Arab pada kedua metafora integrasi ilmu, baik pada pohon ilmu dan cemara ilmu, dengan berbagai makna filosofis yang mendasarinya. Peran paradigma pembelajaran bahasa Arab dalam pencapaian konsep ideal integrasi ilmu dari kedua tokoh melahirkan konsep "ulul albab" oleh Imam Suprayogo yang diimplementasikan dalam bentuk Ma'had alJamiah serta Program Khusus Pengembangan Bahasa Arab (PKPBA) di lingkungan UIN Maulana Malik Ibrahim Malang, serta melahirkan konsep "inner capacity" oleh Azhar Arsyad yang diimplementasikan dalam bentuk Program Pencerahan Imani dan Keterampilan Hidup (PIKIH) di lingkungan UIN Alauddin Makassar.

\section{DAFTAR RUJUKAN}

Abdullah, A. 2006. Islamic Studies di Perguruan Tinggi. Yogyakarta: Pustaka Pelajar.

Arbi, dkk. 2018. Model Pengembangan Paradigma Integrasi Ilmu di Universitas Islam Negeri Sunan Kalijaga Yogyakarta dan Universitas Islam Negeri Maulana Malik Ibrahim Malang. Profetika: Jurnal Studi Islam, 20 (1), 1-15.

Arsyad, A. \& Sabri, M. 2009. Membangun Tradisi Hikmah Mengasah Inner Capacity: Ikbtiar Merancang Paradigma Keilmuan UIN Alauddin Makassar. Makassar: Alauddin Press.

Arsyad, A. 2002. Al-Qiraah al-Ashriyah. Yogyakarta: Pustaka Pelajar.

Arsyad, A. 2005. Jejak Langkah menuju Pusat Peradaban Islam di Indonesia Timur. Dalam Hadi D. Mapuna dkk. (ed.). 2005. Dulu IAIN kini UIN Alauddin: Catatan Tabun Ketiga Kepemimpinan Azbar Arsyad sebagai Rektor IAIN/UIN Alauddin Makassar. Makassar: Alauddin Press.

Arsyad, A. 2009. Pohon Integrasi dan Interkoneksitas Sains dan Ilmu Agama. Dalam Azhar Arsyad et. al. 2009. Membangun Universitas Menuju Peradaban Islam Modern: Catatan Singkat Perjalanan UIN di bawab Kepemimpinan Prof. Dr. H. Az̧ar Arsyad, MA. Makassar: Alauddin Press.

Arsyad, A. 2010. Bahasa Arab dan Metode Pengajarannya: Beberapa Pokok Pikiran. Yogyakarta: Pustaka Pelajar.

Arsyad, A. 2011. Buah Cemara Integrasi dan Interkoneksitas Sains dan Ilmu 
Lughawiyah, Vol. 2, No. 2, Desember 2020

Agama. Hunafa: Jurnal Studia Islamika, 8 (1), 1-25.

Arsyad, A. 2012. Thuruq Tadris al-Lugah al'Arabiyah. Makassar: Matba'ah Jami'ah 'Alaiddin al-Islamiyah alHukumiyah.

Arsyad, A. 2016. Sir Najah Tadris al-Lugah al-'Arabiyah, Makalah. Konferensi Internasional Pembelajaran Bahasa Arab. Dubai, Uni Emirat Arab.

Aziz, R. 2007. Pendidikan Ulul Albab pada Mahasiswa Universitas Islam Negeri (UIN) Malang. Progresiva: Jurnal Pemikiran dan Pendidikan Islam, 2 (1), 307-320.

Darda, A. 2015. Integrasi Ilmu dan Agama: Perkembangan Konseptual di Indonesia. At-Ta'dib, 10 (1), 33-46.

Harahap, S. 2014. Metodologi Studi Tokoh dan Penulisan Biografi. Jakarta: Prenada Media Group.

Mahzar, A. 2004. Revolusi Integralisme Islam: Merumuskan Paradigma Sains dan Teknologi Islam. Bandung: Mizan.

Nuha, U. 2016. Ragam Metodologi dan Media Pembelajaran Bahasa Arab. Yogyakarta: Diva Press.

Ramly, M. 2010. "Cendekiawan Bersahaja, Berkarya Monumental". Dalam Ahmad M. Sewang dkk. (eds.). 2010. Biografi Azhar Arsyad: JejakJejak Langkah Sang Pemimpi. Makassar: Alauddin Press.

Sugiyono. 2008. Metode Penelitian Pendidikan: Pendekatan Kuantitatif, Kualitatif, dan R\&D. Bandung: Alfabeta.

Suprayogo, I. 1996. Urgensi Bahasa Arab dalam Meretas Khazanah Islam Klasik. Jurnal Ilmu dan Pemikiran Keagamaan, 1 (1).
Suprayogo, I. 2005. Paradigma Pengembangan Keilmuan pada Perguruan Tinggi: Konsep Pendidikan Tinggi yang Dikembangkan UIN Malang. Malang: UIN Malang Press.

Suprayogo, I. 2007. Quo Vadis Madrasah: Gagasan, Aksi dan Solusi Pembangunan Madrasah. Yogyakarta: Hikayat Publishing.

Suprayogo, I. 2011. Refleksi Pemikiran Menuju Indonesia Baru. Malang: UINMaliki Press.

Suprayogo, I. 2013. Pengembangan Pendidikan Karakter. Malang: UIN-Maliki Press.

Taufiqurrahman, H. R. 2010. Imam alJamiah: Narasi Indah Perjalanan Hidup dan Pemikiran Prof. Dr. H. Imam Suprayogo. Malang: UIN-Maliki Press. 